\title{
Construction of Rhodococcus random mutagenesis libraries using Tn5 transposition complexes
}

\author{
Paula J. Fernandes, Justin A. C. Powell $†$ and John A. C. Archer \\ Author for correspondence: John A. C. Archer. Tel: +44 1223333 999. Fax: +44 1223333992. \\ e-mail: jaca1@mole.bio.cam.ac.uk
}

Department of Genetics, University of Cambridge, Downing Street, Cambridge CB2 3EH, UK

\begin{abstract}
The ability to generate tagged mutants of Rhodococcus spp. will facilitate a deeper understanding of this medically and commercially important genus. The absence of efficient transposon systems in these organisms has here been overcome by the use of Tn5-based DNA-protein transposition complexes which can transpose at high efficiency. To achieve this, electroporation efficiencies and antibiotic selection were optimized. A Rhodococcus rhodochrous CW25 Tn5 insertion library of 1500 mutants was created. Southern blotting of 23 representative mutants demonstrated random insertion. A number of auxotrophic mutants were isolated and the disrupted regions involved were identified by inverse PCR and subsequent sequencing. Transposition of Tn 5 was confirmed by the presence of 9 bp direct repeats of Rhodococcus DNA flanking the transposon insertion site. To further test this system, a Tn5 insertion library was constructed in a wild-type soil isolate of Rhodococcus spp. This is the first viable transposon knockout system reported for Rhodococcus.
\end{abstract}

Keywords: transposon, kanamycin, Gram-positive, Mycobacterium, Nocardia

\section{INTRODUCTION}

The genus Rhodococcus encompasses a multi-faceted group of bacteria of clinical, industrial and environmental significance. Rhodococcus belongs to a suprageneric group which includes Mycobacterium and Corynebacterium. This group is characterized by the presence of mycolic acids incorporated into the outer cell wall structure. Members are found in soil and ocean environments, and also cause disease in humans and animals (Colquhoun et al., 1998; Goodfellow \& Alderson, 1977).

Originally primarily of veterinary significance, Rhodococcus has become clinically important in the immunocompromised, particularly in patients with AIDS (Mosser \& Hondalus, 1996). Rhodococci and members of related genera such as the nocardiae have been shown to cause a number of complaints, including brain abscesses, sub-acute endocarditis and pulmonary disease (Berkowitz, 1994).

Rhodococcus appears specialized to recycle complex plant-derived compounds in the soil, including a wide

†Present address: Paradigm Therapeutics, Department of Physiology, Downing Street, Cambridge, CB2 3EG, UK.

Abbreviation: $\mathrm{P} P \mathrm{CR}$, inverse $\mathrm{PCR}$. range of aromatic hydrocarbons. As a result, Rhodococcus isolates have been shown to catalyse a wide range of biotransformations of industrial relevance, such as xenobiotic degradation and surfactant synthesis (Goodfellow \& Alderson, 1977; Larkin et al., 1998; Warhurst \& Fewson, 1994), and the manufacture of other commercially important products (Allen et al., 1997; Larkin et al., 1998).

Currently, Rhodococcus genetics lacks a transposon system which functions efficiently enough to permit the generation of comprehensive random insertion libraries. Such systems have been widely used in the characterization of genes in Escherichia coli and many other genera (Kleckner, 1981). The development of these systems for many Gram-positive bacteria (in particular the recalcitrant actinomycetes) has, until recently, been hampered by a general lack of genetic tools. In a strain of Rhodococcus fascians, tagged mutagenesis has been achieved by the random illegitimate insertion into the chromosome of suicide vectors delivered by electroporation (Crespi et al., 1994). However, high frequencies of illegitimate recombination have not been observed upon introduction of various non-replicating vectors into other strains of Rhodococcus; consequently this technique is not generally applicable (Powell \& Archer, 1998; Shao \& Behki, 1995; Yao et al., 1994a). 
In vivo transposition systems based on suicide delivery suffer from the combined effects of low transformation efficiency in wild-type strains and low transposition frequency, precluding the generation of insertion libraries (Guilhot et al., 1994; Pelicic et al., 1997). Replicative delivery systems avoid this problem but require both a functioning replicon and a means of selecting for transposition events. Selection can be achieved with a counter-selectable marker such as $s a c B$, a temperature-sensitive replicon, or by insertional activation of a promoterless antibiotic resistance gene carried on the transposable element. In Mycobacterium tuberculosis, it has proven necessary to use both $s a c B$ counter-selection and temperature-sensitive plasmid replicons simultaneously to ensure clean selection (Pelicic et al., 1997). The use of replicative vectors runs a risk of generating a large number of sibling colonies due to the sustained period of growth prior to selection. Although a number of Rhodococcus IS elements have been isolated, none have been engineered into a usable mutagensis system (Denome \& Young, 1995; Jager et al., 1995; Lessard et al., 1999; Nagy et al., 1997; Yao et al., 1994a).

In vitro mutagenesis of DNA using the Tn552 system followed by integration back into the host chromosome has proven effective in Mycobacterium smegmatis. This approach depends on the frequency of homologous recombination, which has been shown to be low in strains of Rhodococcus (Barnes et al., 1997; Powell \& Archer, 1998) and its utility in this genus has yet to be demonstrated.

The recent development of the Tn5-based 'Transposome' system eliminates a number of these problems. Tn5 is one of the simplest and best characterized transposons. In vitro transposition requires only $\mathrm{Tn} 5$ transposase, transposon DNA flanked by Tn5 inverted repeats, and target DNA. The transposome system consists of Tn 5 transposase bound to transposon DNA in vitro. This bound complex is prevented from completion of the transposition reaction by the absence of magnesium ions. Following electroporation of the protein-DNA complex into a bacterial cell, the reaction proceeds due to the presence of magnesium ions, resulting in insertion of the transposon DNA at random into the genome. For a poorly characterized host like Rhodococcus this approach has a number of advantages. Firstly, the expression of transposase in the target strain is not required. Secondly, the transposition frequency once the complex has been transformed into the cell is very high. There is therefore no requirement for replicative delivery and the concomitant problems of selecting for transposition events. Transposome insertion frequencies are limited only by the rate of DNA transformation. The lack of requirement for hostencoded factors means that the system has the potential to operate in a very wide range of organisms (Goryshin et al., 2000).

The use of this system in the genus Rhodococcus or the related genera Corynebacterium, Nocardia or Mycobacterium has not previously been investigated. In this paper we describe the use of the EZ::TN(KAN-2)Tnp Transposome to create random transposon libraries in Rhodococcus rhodochrous CW25 and in a wild-type Rhodococcus soil isolate. The transposable element in this case consists of the Tn903 kanamycin resistance gene flanked by two 19 bp Tn5 inverted repeats. During the course of this work the use of the kanamycinresistance transposome to create a transposon library in M. smegmatis was reported (Derbyshire et al., 2000).

\section{METHODS}

Bacterial strains and plasmids. $R$. rhodochrous CW25 was a gift from E. Dabbs, University of the Witwatersrand, South Africa. Rhodococcus sp. RC89, isolated from a polluted gasworks site in Newcastle, was a gift from R. Cain, University of Newcastle. The broad-host-range plasmid pCY104 (Yao et al., 1994b) containing the Tn903 kanamycin resistance gene and the thiostrepton resistance gene from Streptomyces azureus was used to test electroporation efficiencies and antibiotic selection. pCY104 DNA was isolated from E. coli XL1-Blue (Stratagene). Rhodococcus spp. were routinely grown on Luria-Bertani (LB) medium (Difco) with Bacto Agar $\left(16 \mathrm{~g} \mathrm{l}^{-1}\right)$ added for plates (LA). Auxotrophic and hydrocarbon utilization screens were carried out on minimal media (Dabbs, 1987) supplemented with the relevent carbon source $(25 \mathrm{mM}$ succinate or $200 \mu \mathrm{l}$ toluene or benzene provided in an Eppendorf tube inside the agar plate). Growth of $R$. rhodochrous CW25 on minimal media required the addition of $100 \mu \mathrm{g}$ phenylalanine $\mathrm{ml}^{-1}, 40 \mu \mathrm{g}$ glutamic acid $\mathrm{ml}^{-1}$ and $5 \mu \mathrm{g}$ thiamin $\mathrm{ml}^{-1}$; Rhodococcus sp. RC89 did not require any additional supplements. Cultures grown in complex media were incubated at $30^{\circ} \mathrm{C}$ for $2-3 \mathrm{~d}$ and liquid cultures were shaken. Cultures grown in minimal media were incubated at room temperature for 3-7 d.

Transformation of Rhodococcus spp. Ten millilitres of a stationary-phase culture was used to inoculate a $500 \mathrm{ml}$ flask containing $200 \mathrm{ml} \mathrm{LB}$ supplemented with $2 \%$ (w/v) glycine for $R$. rhodochrous CW 25 and $1 \%$ glycine plus $0.5 \%(\mathrm{w} / \mathrm{v})$ glucose for Rhodococcus sp. RC89. The flask was incubated at $30{ }^{\circ} \mathrm{C}$ with shaking until the culture reached late exponential phase or an $\mathrm{OD}_{550}$ of no more than 0.9 units using a Beckman DU 650 spectrophotometer. Cells were then incubated on ice for $20 \mathrm{~min}$ and pelleted by centrifugation (Sorvall RC-5B) at 4000 r.p.m. for $20 \mathrm{~min}$ at $4{ }^{\circ} \mathrm{C}$. The cell pellet was washed twice in $100 \mathrm{ml}$ sterile $10 \%(\mathrm{v} / \mathrm{v})$ glycerol. Washes were carried out at $4{ }^{\circ} \mathrm{C}$ and cells were stored on ice at all other times. Aliquots $(3 \mu \mathrm{l})$ of cells were diluted in $1 \mathrm{ml} \mathrm{LB}$ and the $\mathrm{OD}_{550}$ was measured. The concentration of cells for electroporation was adjusted to give an $\mathrm{OD}_{550}$ of 0.4 in the diluted sample.

Mutagenesis. Electrocompetent Rhodococcus cells $(40 \mu \mathrm{l})$ were placed on ice in a $0.1 \mathrm{~cm}$ electrode gap Bio-Rad electroporation cuvette and mixed with $20 \mathrm{ng}(1 \mu \mathrm{l})$ EZ::TN(KAN-2)Tnp Transposome (Epicentre Technologies). Electroporation was carried out at $1.6 \mathrm{kV}, 25 \mu \mathrm{F}$, $200 \Omega$. Cells were resuspended in $1 \mathrm{ml} \mathrm{SMME} \mathrm{(0.7} \mathrm{M} \mathrm{sucrose,}$ $50 \mathrm{mM}$ maleic acid, $10 \mathrm{mM} \mathrm{MgCl} 2 \cdot 6 \mathrm{H}_{2} \mathrm{O}$ and $10 \mathrm{mM} \mathrm{CaCl}_{2}$, pH 6.5) (Haynes \& Britz, 1990) and immediately plated in $100 \mu \mathrm{l}$ aliquots onto LA plates containing $1 \%$ glucose. Plates were incubated for $12 \mathrm{~h}$ at $30^{\circ} \mathrm{C}$, then overlaid with soft agar containing sufficient kanamycin to give a final concentration of antibiotic in the plate (taking the volume of LA into account) of $400 \mu \mathrm{g} \mathrm{ml}^{-1}$ for $R$. rhodochrous CW25 and $100 \mu \mathrm{g} \mathrm{ml}^{-1}$ for Rhodococcus sp. RC89. The soft agar was 
allowed to set and plates incubated at $30{ }^{\circ} \mathrm{C}$. Transposants appeared within $5 \mathrm{~d}$.

DNA extraction and manipulation. DNA extractions were based on the salting out method of Pospiech \& Neumann (1995). Rhodococcus cultures were grown in $10 \mathrm{ml} \mathrm{LB}$ containing the appropriate concentration of kanamycin and pelleted (Sorvall RC-5B) at 4500 r.p.m. for $12 \mathrm{~min}$. Samples were resuspended in $5 \mathrm{ml} \mathrm{SET}$ buffer $(75 \mathrm{mM} \mathrm{NaCl}, 25 \mathrm{mM}$ EDTA pH 8, $20 \mathrm{mM}$ Tris $\mathrm{pH} 7 \cdot 5)$. Lysozyme $\left(5 \mathrm{mg} \mathrm{ml}^{-1}\right)$ was added and samples were incubated at $37^{\circ} \mathrm{C}$ for $1 \mathrm{~h}$ with shaking. Proteinase $\mathrm{K}$ ( $1 \mathrm{mg} \mathrm{ml}^{-1}$ final concentration) plus $2 \%$ (w/v) SDS (final concentration) were then added and samples were incubated at $60^{\circ} \mathrm{C}$ for $2 \mathrm{~h}$. $\mathrm{NaCl}(5 \mathrm{M} ; 2 \mathrm{ml})$ was added; the samples were mixed and allowed to cool to less than $37^{\circ} \mathrm{C}$. Chloroform $(5 \mathrm{ml})$ was then added and the samples were incubated at $4{ }^{\circ} \mathrm{C}$ for $30 \mathrm{~min}$ with shaking. Cell debris was pelleted by centrifugation at 4500 r.p.m. at $4{ }^{\circ} \mathrm{C}$ and supernatants transferred to a $15 \mathrm{ml}$ Corex tube. DNA was precipitated with $0.6 \mathrm{vol}$. 2-propanol at $-20^{\circ} \mathrm{C}$ for $1 \mathrm{~h}$ and recovered by centrifugation at 8000 r.p.m. for $15 \mathrm{~min}$. DNA pellets were left to dry and were then resuspended in $100 \mu \mathrm{l}$ warm sterile distilled water.

Restriction enzymes and T4 DNA ligase were from New England Biolabs and were used according to the manufacturer's instructions. Ligations were carried out at room temperature for $2 \mathrm{~h}$.

Southern hybridization. Probes were labelled by the incorporation of digoxigenin-11-dUTP by PCR using the Roche PCR DIG Probe Synthesis Kit, used according to the manufacturer's instructions. All hybridizations were carried out using the DIG system for filter hybridization (Roche) according to the manufacturer's instructions. DNA was transferred onto positively charged nylon membranes (Boehringer Mannheim) and fixed by UV cross-linking. Hybridization and post-hybridization washes were carried out at $68^{\circ} \mathrm{C}$ in a Hybaid 'shake'n'stack' hybridization oven.

Inverse PCR (iPCR). To sequence tagged genome insertions, total DNA was extracted and 1-2 $\mu \mathrm{g}$ samples were digested with the appropriate restriction enzymes $(M l u \mathrm{I}, \mathrm{NcoI}$ and Pst $\mathrm{I}$ were used). Digested DNA was cleaned up by extraction with phenol/chloroform $(1: 1)$ and precipitated with 2-propanol. Digested samples for each transposant were pooled in $17 \mu \mathrm{l}$ sterile distilled water and ligation carried out at room temperature for $2 \mathrm{~h}$. Ligations were heat-killed and then dropdialysed for $1 \mathrm{~h}$ on $0.025 \mu \mathrm{m}$ Millipore filters before proceeding to iPCR. After drop dialysis, iPCR was carried out as follows using GibcoBRL reagents: $1 \times$ PCR buffer, $1.5 \mathrm{mM} \mathrm{MgCl}_{2}$, $200 \mu \mathrm{M}$ of each dNTP (Promega), $0 \cdot 2 \mu \mathrm{M}$ of forward primer (KAN-2 FP-1, 5'-ACCTACAACAAAGCTCTCATCAACC$\left.3^{\prime}\right)$ and of reverse primer (KAN-2 RP-1, 5'-GCAATGTAACATCAGAGATTTTGAG-3'), 2.5 U Taq DNA polymerase and $1 \mu \mathrm{l}$ template DNA (from ligation). Sterile distilled water was added to a final volume of $50 \mu \mathrm{l}$. PCR reaction conditions were as follows: initial denaturation at $96{ }^{\circ} \mathrm{C}$ for $5 \mathrm{~min}$; followed by 30 cycles of denaturation at $95^{\circ} \mathrm{C}$ for $30 \mathrm{~s}$, annealing at $56^{\circ} \mathrm{C}$ for $1 \mathrm{~min}$ and extension at $72^{\circ} \mathrm{C}$ for $1 \mathrm{~min}$; with a final extension at $72^{\circ} \mathrm{C}$ for $5 \mathrm{~min}$. Following iPCR, samples were run on $0.85 \%$ agarose gels, products were cut out and DNA extracted using the Concert rapid gel extraction system (GibcoBRL). Finally, salt was removed by drop dialysis of samples prior to sequencing.

DNA sequencing and analysis. Sequencing reactions were carried out using ABI PRISM BigDye sequencing kits on an ABI PRISM 377 DNA sequencer. KAN-2 FP-1 and KAN-2 RP-
1 primers used for iPCR were also used for sequencing. Sequences were assembled using Staden software programs PREGAP and GAP4 (Bonfield et al., 1995) on a Silicon Graphics Unix computer. DNA and protein similarity searches were carried out with BLAST 2.0 using the WWW interface at the NCBI (National Center for Biotechnology Information) (Altschul et al., 1997). The Prosite (Bairoch et al., 1997) and Pfam (Sonnhammer et al., 1998) profile databases were searched using the server of the Bioinformatics group at the ISREC (Swiss Institute for Experimental Cancer Research) and the ExPASy WWW molecular biology server of the Geneva University Hospital and the University of Geneva. Other analyses were carried out using the GCG (Genetics Computer Group, Madison, Wisconsin) package, version 9.1.

\section{RESULTS}

\section{Optimization of $R$. rhodochrous CW25 electroporation}

R. rhodochrous CW25 was used to test the transposome mutagenesis system as this strain has been widely used by researchers (Bresler et al., 2000) and has a high electroporation efficiency.

The generation of significant numbers of insertion mutants using the transposome system is critically dependent on the electroporation efficiency of the strain, particularly with heterologously derived DNA, as is the case for both pCY104 and the transposome system. Electroporation efficiencies are most easily measured using a replicative vector. Highly electrocompetent $E$. coli will generate $10^{9}$ c.f.u. $\mu^{-1}$ of replicative, homologously derived plasmid DNA and $10^{5}$ c.f.u. $(20 \mathrm{ng})^{-1}$ of transposome preparation. Such high efficiencies with replicative plasmid DNA are not readily achievable using wild-type strains of Rhodococcus and it would therefore be expected that the number of transposome insertions generated would also be lower.

It has been shown that recovery after electroporation on solid media prior to selection results in a higher frequency of transformants than recovery in liquid media (Powell, 1998). Although selection can be carried out by resuspension of the cells from non-selective solid media and subsequent replating on selective media, this generates a significant number of sibling colonies, thus obscuring the true number of independent transformants. To overcome this problem, the use of soft agar overlays was investigated. Kanamycin levels ranged from 50 to $450 \mu \mathrm{g} \mathrm{ml}^{-1}$. Using $R$. rhodochrous CW 25 it was found that at levels below $400 \mu \mathrm{g} \mathrm{ml}^{-1}$ a significant number of spontaneous resistant mutants arose, whereas at levels above $500 \mu \mathrm{g} \mathrm{ml}^{-1}$ the number of transformants was reduced. A soft agar overlay supplemented with kanamycin to give a final concentration of $400 \mu \mathrm{g} \mathrm{ml}^{-1}$ in each plate was therefore used to select transformants for the remainder of the work.

To determine the optimum recovery time after electroporation, $100 \mu \mathrm{l}$ of each sample was plated onto LAG (Luria agar with $1 \%$ glucose) and incubated at $30^{\circ} \mathrm{C}$ for 0,6 and $12 \mathrm{~h}$ prior to addition of selective overlay. Selection immediately after plating cells on LA with 


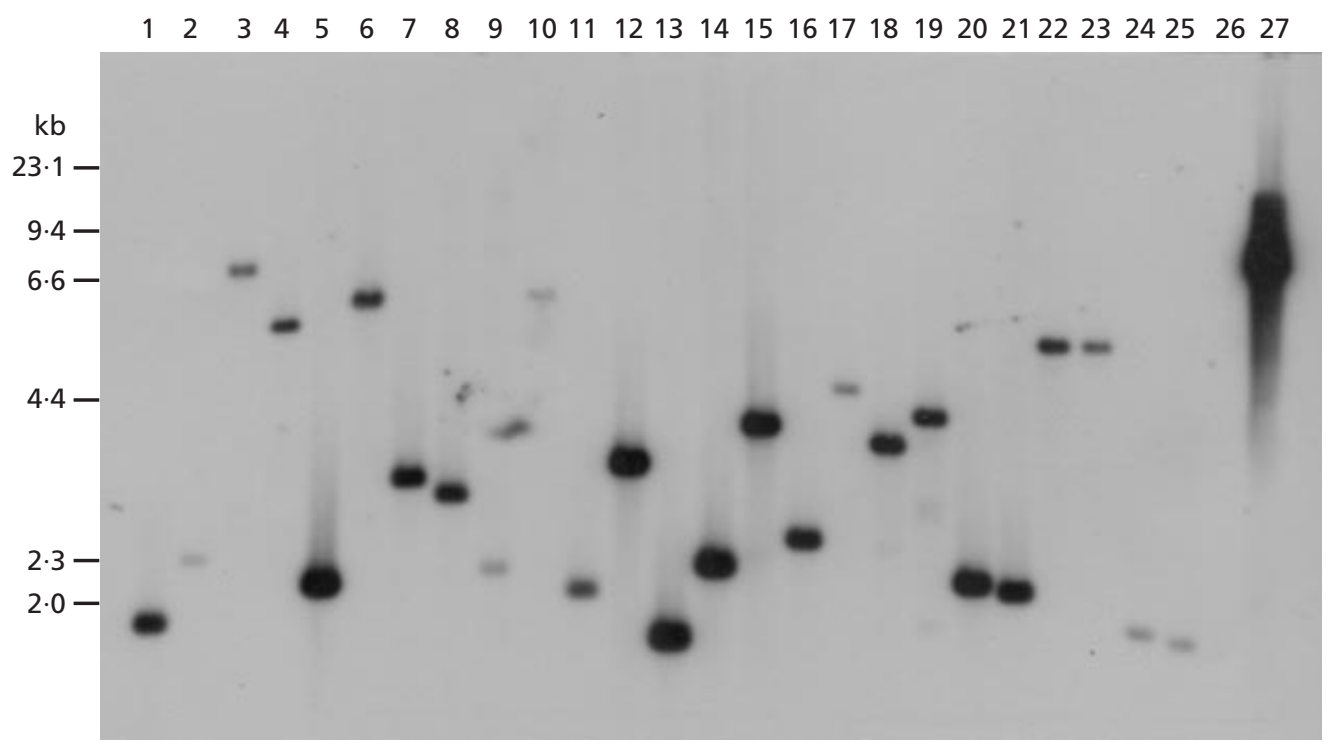

Fig. 1. Efficient transposition of a Tn5 transposome in Rhodococcus. Lanes $1-21$ and $24-25$ contain total DNA from putative $R$. rhodochrous CW25 transposants probed with the DIG-labelled Tn903 kanamycin gene. Lane 26 contains $R$. rhodochrous CW25 DNA not subjected to transposon mutagenesis. Lane 27 contains the Tn903 kanamycin-carrying plasmid pVJT131 as a positive control. This blot shows that each of the kanamycin-resistant colonies chosen at random contained an individual transposition event. Furthermore, of all 23 transposants chosen from the overlay selection, none shared the same insertion site. Lanes 22 and 23 contain DNA from sibling mutants from an earlier experiment in which the overlay technique was not used. They show bands in common as the siblings arose due to the nature of transposant recovery. Positions of markers (HindIII-digested $\lambda$ DNA) are shown on the left.

glucose greatly reduced efficiency, $5 \times 10^{3}$ c.f.u. $(0 \cdot 5 \mu \mathrm{g}$ DNA ${ }^{-1}$, as compared with those allowed to recover for longer periods post-electroporation. The longer recovery times of 6 and $12 \mathrm{~h}$ gave rise to $2 \times 10^{4}$ and $7 \times 10^{4}$ c.f.u. $(0 \cdot 5 \mu \mathrm{g} D N A)^{-1}$, respectively. After $12 \mathrm{~h}$ of recovery, the number of transformants was increased 14fold compared with immediate plating onto selective media. If cells were left to recover for longer periods (more than $12 \mathrm{~h}$ ), the amount of background growth no longer allowed for selection of transformants.

Growth on glycine and/or isoniazid has been shown to enhance the electroporation efficiencies of strains of Corynebacterium glutamicum (Haynes \& Britz, 1990), Mycobacterium bovis BCG (Cho et al., 1998) and Rhodococcus equi (Sekizaki et al., 1998), most likely by affecting growth of the cell wall. $R$. rhodochrous CW 25 grown in the presence of glycine $(2 \%)$, or glycine $(2 \%)$ plus isoniazid $\left(100 \mu \mathrm{g} \mathrm{ml}^{-1}\right)$ gave rise to a 10 -fold increase $\left[7 \times 10^{5}\right.$ c.f.u. $\left.(0.5 \mu \mathrm{g} \mathrm{DNA})^{-1}\right]$ in electroporation efficiency (using the replicative vector pCY104) as compared to cells grown in unsupplemented media. These high-efficiency cells were stored at $-70{ }^{\circ} \mathrm{C}$ and subsequently used for electroporation with transposome.

\section{Electroporation with transposome}

A preliminary experiment was carried out in which $R$. rhodochrous CW25 (grown without media supplementation) was electroporated with $20 \mathrm{ng}$ of the trans- posome preparation and spread onto non-selective LA plates. Following overnight incubation, cells were resuspended and plated onto LA supplemented with $400 \mu \mathrm{g}$ kanamycin $\mathrm{ml}^{-1}$. A number of transposants were isolated and chromosomal insertions confirmed by Southern blotting, but electroporation/transposition frequencies could not be determined as the nature of the recovery gave rise to large numbers of siblings (data not shown). To confirm these results, the experiment was repeated using the glycine-grown electrocompetent cells described above. Transposants were selected using the kanamycin overlay technique to prevent isolation of sibling colonies. One thousand five hundred kanamycinresistant colonies were obtained from 20 ng transposome complex.

\section{Confirmation of insertion by Southern blotting}

To confirm insertion of the transposome, chromosomal DNA was prepared from 23 transposant colonies chosen at random. The genomic DNA was digested to completion with PstI and Southern blot analysis was performed using the Tn903 kanamycin resistance gene as a probe. The Southern blot shown in Fig. 1 demonstrates that all insertions were unique and random insertion of the transposon occurred, in all cases at different places on the chromosome with the exception of the colonies in lanes 22 and 23, which were siblings from the preliminary experiment described earlier in which the overlay technique was not used. These results 
were confirmed by an additional blot in which samples were digested with EcoRI (data not shown).

\section{Confirmation of $\operatorname{Tn} 5$ transposition by sequencing}

When transformed into strains of Rhodococcus and Mycobacteria, circular and linear DNA molecules have been shown in some instances to undergo illegitimate recombination with the chromosome (Desomer et al., 1991; Kalpana et al., 1991; Larkin et al., 1998). Transposase-mediated Tn5 insertions are characterized by the generation of $9 \mathrm{bp}$ direct repeats (Berg et al., 1988) in the host DNA flanking the insertion. To establish whether the transposome DNA had been inserted into the Rhodococcus genome by illegitimate recombination or by transposition, the sequence of the DNA flanking the insertions was determined by sequencing the iPCR products generated from 10 representative mutants. The sequence data results (six mutants displayed) show the presence of $9 \mathrm{bp}$ direct repeats in the host DNA flanking the transposable element (Fig. 2), thus proving that transposition has occurred.

\section{Auxotrophy screen}

To test the comprehensiveness of this library, $800 R$. rhodochrous CW25 mutants were patched onto minimal media with and without Casamino acids $\left(880 \mu \mathrm{g} \mathrm{ml}^{-1}\right)$. Of the 800 mutants, $20(2.5 \%)$ failed to grow on minimal media without Casamino acids, as expected from earlier publications which reported similar results (Desomer et al., 1991). Auxotrophic phenotypes of seven mutants were deduced by supplementation with amino acids (Davis et al., 1982) and transposon insertion sites sequenced. Table 1 summarizes the phenotypic and genotypic data on auxotrophic mutants. In each case the phenotype corresponds to that expected based on the disrupted gene.

\section{Library construction in Rhodococcus sp. RC89}

The wild-type soil isolate Rhodococcus sp. RC89 was selected for its ability to catabolize a wide range of aromatic hydrocarbons. Unlike $R$. rhodochrous $\mathrm{CW} 25$, Rhodococcus sp. RC89 has not been subjected to laboratory manipulation.

Rhodococcus sp. RC89 was transformed by electroporation with pCY104 and allowed to recover on LA with $1 \%$ glucose for $12 \mathrm{~h}$ at $30^{\circ} \mathrm{C}$. Soft agar overlays were added to give a range of final kanamycin concentrations from 100 to $400 \mu \mathrm{g} \mathrm{ml}^{-1}$. A concentration of $100 \mu \mathrm{g}$ kanamycin $\mathrm{ml}^{-1}$ was found to be optimal. The pCY104 transformation efficiency of Rhodococcus sp. RC89 was $3 \times 10^{4}$ c.f.u. $(0 \cdot 5 \mu \mathrm{g} \mathrm{DNA})^{-1}$.

Electroporation with $20 \mathrm{ng}(1 \mu \mathrm{l})$ transposome gave rise to 500 Rhodococcus sp. RC89 transposants. Four hundred transposants were patched onto minimal media
B

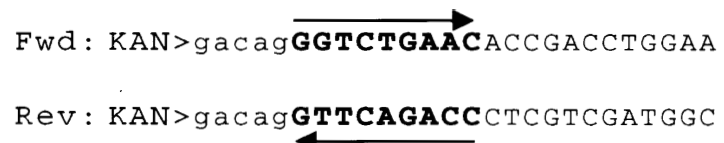

C

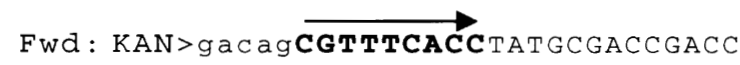

Rev: KAN>gacagGGTGAAACGCATCCTCAGCCCG

E

Fwd: KAN>gacag $\overrightarrow{\text { GGATAGGCTGACTCGAAGAGTT }}$

Rev: KAN>gacagAGCCTATCCTCCGCGATGAGGC

F

Fwd : KAN>gacagAGTGGGGCCTTCCCGGTCAGCG

Rev: KAN>gacagGGCCCCACTGGCCGAGGAAAAT

$P$

Fwd: KAN > gacag $\overrightarrow{\mathbf{A C C G G G A T G}}$ ACCCACCGCGGCG

Rev : KAN>gacagCA TCCCGGTCCTGCGGCGACGG

$\mathrm{R}$

Fwd: KAN>gacagGCTCCGGACATACCCCGGCAAG
Rev: KAN>gacagGTCCGGAGCACTGCCGTGAACG

Fig. 2. Confirmation of Tn5 transposition by sequencing transposon/Rhodococcus junctions. Sequences of six putative transposants are shown here, mutants B, C and E picked at random and auxotrophic mutants $F, P$ and $R$. Sequencing reactions using the forward and reverse primers (KAN-2 FP-1 and KAN-2 RP-1) were carried out. Five base pairs (gacag) of the Tn5 inverted repeats are shown flanking the Tn903 kanamycin resistance gene (KAN $>$ ). Nine base pair repeats of Rhodococcus DNA flanking the transposon are shown in bold (arrows indicate repeat sequence orientation). Sequencing of 10 out of 10 (additional 4 not shown) R. rhodochrous CW25 transposants revealed 9 bp repeats in the Rhodococcus genome at the insertion site of Tn5.

with succinate and $24(6.5 \%)$ failed to grow, indicating efficient library coverage. Around 200 mutants were screened for their inability to utilize toluene and benzene as sole sources of carbon and energy. Two mutants incapable of utilizing these compounds and five further mutants that grew slowly on them were isolated. The insertion site of one of the mutants was sequenced and transposition confirmed by the presence of 9 bp repeats. The disrupted gene was $57 \%$ identical to a diaminobutyric acid aminotransferase from Bacillus halodurans (NCBI accession no. BAB04638). As there is no evidence to suggest that this gene product is involved in the 
Table 1. Summary of auxotrophic requirements and associated genes of $R$. rhodochrous CW25 auxotrophic mutants

\begin{tabular}{|c|c|c|c|}
\hline Auxotroph & $\begin{array}{l}\text { Auxotrophic } \\
\text { requirement }\end{array}$ & Associated genes & $\begin{array}{l}\text { NCBI } \\
\text { accession } \\
\text { no. }\end{array}$ \\
\hline A & Isoleucine/valine & $\begin{array}{l}70 \% \text { identical to acetolactate synthase } \\
(\text { ilvB) from } M . \text { tuberculosis }\end{array}$ & O53250 \\
\hline $\mathrm{D}$ & $\begin{array}{l}\text { Isoleucine (weak growth } \\
\text { in the presence of } \\
\text { other amino acids) }\end{array}$ & $\begin{array}{l}80 \% \text { identical to dihydroxy-acid } \\
\text { dehydratase }(i l v D) \text { from } \\
\text { C. glutamicum }\end{array}$ & CAB57218 \\
\hline $\mathrm{I}$ & Methionine & $\begin{array}{l}77 \% \text { identical to } \\
\text { 5-methyltetrahydrofolate- } \\
\text { homocysteine methyltransferase } \\
(\text { met } H) \text { from M. tuberculosis }\end{array}$ & O33259 \\
\hline $\mathrm{L}$ & Isoleucine & $\begin{array}{l}64 \% \text { identical to threonine dehydratase } \\
(\text { ilvA) from C. glutamicum }\end{array}$ & Q04513 \\
\hline $\mathrm{P}$ & Methionine/cysteine & $\begin{array}{l}55 \% \text { identical to a probable } \\
\text { uriporphyrin-III methyltransferase } \\
\text { (cysG2) from M. tuberculosis }\end{array}$ & B70589 \\
\hline $\mathrm{R}$ & Leucine & $\begin{array}{l}74 \% \text { identical to } 3 \text {-isopropylmalate } \\
\text { dehydrogenase }(\text { leuB) from } \\
\text { C. glutamicum }\end{array}$ & P94631 \\
\hline$S$ & Isoleucine/valine & $\begin{array}{l}77 \% \text { identical to acetolactate synthase } \\
(i l v B) \text { from } M \text {. avium }\end{array}$ & Q59498 \\
\hline
\end{tabular}

degradation of monoaromatic hydrocarbons, it is likely that the associated phenotype is due to a polar effect. A number of Rhodococcus sp. RC89 aromatic hydrocarbon degradation mutants are currently under investigation.

\section{DISCUSSION}

Using electrocompetent E. coli $\left[10^{9}\right.$ transformants $(\mu \mathrm{g}$ replicative DNA $)^{-1}$ ], $10^{5}$ transposants can be obtained from $20 \mathrm{ng}$ transposome. In comparison, $1.5 \times 10^{3}$ transposants were obtained from 20 ng transposome electroporated into $R$. rhodochrous CW25 [electroporation efficiency of $10^{5}$ ( $\mu \mathrm{g}$ replicative DNA $)^{-1}$ ]. Thus, when normalized against replicative plasmid transformation efficiencies, the transposition frequency appears to be 100 -fold higher than E. coli. These figures may, however, be misleading as electroporation of E. coli-derived plasmid DNA into Rhodococcus is often subject to restriction, which can reduce electroporation efficiencies up to $10^{4}$-fold when compared with Rhodococcusderived plasmid DNA (Powell, 1998). Restriction is dependent on the presence of the enzyme recognition sequence in the introduced DNA. The short $1 \mathrm{~kb}$ transposome DNA is less likely to contain such recognition sequences than the $8 \mathrm{~kb}$ pCY104 vector used to derive the replicative vector efficiencies. Restriction of pCY104 could therefore increase apparent normalized transposition frequency in Rhodococcus. Thus the short transposome DNA is at a distinct advantage compared with larger plasmid-based suicide vectors when dealing with restriction competent strains.
Because of polar effects, it is difficult to calculate exactly the number of insertions required for a high confidence library. However, given a plausible genome complement of 4000 genes arranged in 2500 transcriptional units, this number should lie between 3000 and 10000 insertions (Blattner et al., 1997). This number is readily achievable by simple scale-up with the system described in this paper for both $R$. rhodochrous CW25 and the wild-type strain Rhodococcus sp. RC89. Library construction would be facilitated by optimization of the electroporation efficiency for each strain. We have found that pCY104 has a particularly broad host range amongst the rhodococci and is therefore an ideal test vector. This is the first report of transposon mutagenesis on this scale in Rhodococcus.

The advantages of this system over the standard in vivo transposase expression approach are the high efficiency, the lack of requirement for complex replicative vectors or native inducible promoters to drive transposase expression, and the generation of unique insertions without risk of isolating sibling colonies (using the overlay technique described here). Transposome electroporation is likely to become the method of choice for generating transposon insertion libraries in Rhodococcus.

\section{ACKNOWLEDGEMENTS}

The authors would like to thank Dr Duncan Rowe for helpful discussions and acknowledge funding support from BBSRC, Cambridge Microbial Technologies and the D. J. Fielding Medical Research Trust. 


\section{REFERENCES}

Allen, C. C. R., Boyd, D. R., Larkin, M. J., Reid, K. A., Sharma, N. D. \& Wilson, K. (1997). Metabolism of naphthalene, 1-naphthol, indene, and indole by Rhodococcus sp. strain NCIMB 12038. Appl Environ Microbiol 63, 151-155.

Altschul, S. F., Madden, T. L., Schaffer, A. A., Zhang, J., Zhang, Z., Miller, W. \& Lipman, D. J. (1997). Gapped BLAST and PSI-BLAST : a new generation of protein database search programs. Nucleic Acids Res 25, 3389-3402.

Bairoch, A., Butcher, P. \& Hofmann, K. (1997). The PROSITE database, its status in 1997. Nucleic Acids Res 25, 217-221.

Barnes, M. R., Duetz, W. A. \& Williams, P. A. (1997). A 3-(3hydroxyphenyl)propionic acid catabolic pathway in Rhodococcus globerulus PWD1: cloning and characterization of the $h p p$ operon. J Bacteriol 179, 6145-6153.

Berg, D. E., Kazic, T., Phadnis, S. H., Dodson, K. W. \& Lodge, J. K. (1988). Mechanism and regulation of transposition. In Transposition (Society for General Microbiology Symposium 43), pp. 107-129. Edited by A. J. Kingsman, K. F. Chater \& S. M. Kingsman. Cambridge: Cambridge University Press.

Berkowitz, F. E. (1994). The gram-positive bacilli - a review of the microbiology, clinical aspects, and antimicrobial susceptibilities of a heterogeneous group of bacteria. Pediatr Infect Dis J 13, 1126-1138.

Blattner, F. R., Plunkett, G., 3rd, Bloch, C. A. \& 14 other authors (1997). The complete genome sequence of Escherichia coli K-12. Science 277, 1453-1474.

Bonfield, J. K., Smith, K. F. \& Staden, R. (1995). A new DNA sequence assembly program. Nucleic Acids Res 23, 4992-4999.

Bresler, M. M., Rosser, S. J., Basran, A. \& Bruce, N. C. (2000). Gene cloning and nucleotide sequencing and properties of a cocaine esterase from Rhodococcus sp. strain MB1. Appl Environ Microbiol 66, 904-908.

Cho, S. N., Hwang, J. H., Park, S., Chong, Y. S., Kim, S. K., Song, C. Y. \& Kim, J. D. (1998). Factors affecting transformation efficiency of BCG with a Mycobacterium-Escherichia coli shuttle vector pYUB18 by electroporation. Yonsei Med J 39, 141-147.

Colquhoun, J. A., Mexson, J., Goodfellow, M., Ward, A. C., Horikoshi, K. \& Bull, A. T. (1998). Novel rhodococci and other mycolate actinomycetes from the deep sea. Antonie Leeuwenhoek 74, 27-40.

Crespi, M., Vereecke, D., Temmerman, W., Vanmontagu, M. \& Desomer, J. (1994). The Fas operon of Rhodococcus fascians encodes new genes required for efficient fasciation of host plants. J Bacteriol 176, 2492-2501.

Dabbs, E. R. (1987). A generalized transducing bacteriophage for Rhodococcus erythropolis. Mol Gen Genet 206, 116-120.

Davis, R. W., Botstein, D. \& Roth, J. R. (1982). A Manual for Genetic Engineering: Advanced Bacterial Genetics. Cold Spring Harbor, NY: Cold Spring Harbor Laboratory.

Denome, S. A. \& Young, K. D. (1995). Identification and activity of two insertion sequence elements in Rhodococcus sp. strain IGTS8. Gene 161, 33-38.

Derbyshire, K. M., Takacs, C. \& Huang, J. (2000). Using the

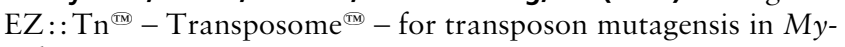
cobacterium smegmatis. Epicentre Forum 7, 1-4.

Desomer, J., Crespi, M. \& Van Montagu, M. (1991). Illegitimate integration of non-replicative vectors in the genome of Rhodococcus fascians upon electrotransformation as an insertional mutagenesis system. Mol Microbiol 5, 2115-2124.

Goodfellow, M. \& Alderson, G. (1977). The actinomycete genus
Rhodococcus: a home for the "rhodochrous" complex. J Gen Microbiol 100, 99-122.

Goryshin, I. Y., Jendrisak, J., Hoffman, L. M., Meis, R. \& Reznikoff, W. S. (2000). Insertional transposon mutagenesis by electroporation of released Tn5 transposition complexes. Nature Biotechnol 18, 97-100.

Guilhot, C., Otal, I., Vanrompaey, I., Martin, C. \& Gicquel, B. (1994). Efficient transposition in mycobacteria - construction of Mycobacterium smegmatis insertional mutant libraries. J Bacteriol 176, 535-539.

Haynes, J. A. \& Britz, M. L. (1990). The effect of growth conditions of Corynebacterium glutamicum on the transformation frequency obtained by electroporation. J Gen Microbiol 136, 255-263.

Jager, W., Schafer, A., Kalinowski, J. \& Puhler, A. (1995). Isolation of insertion elements from Gram-positive Brevibacterium, Corynebacterium and Rhodococcus strains using the Bacillus subtilis sacB gene as a positive selection marker. FEMS Microbiol Lett 126, 1-6.

Kalpana, G. V., Bloom, B. R. \& Jacobs, W. R. (1991). Insertional mutagenesis and illegitimate recombination in mycobacteria. Proc Natl Acad Sci U S A 88, 5433-5437.

Kleckner, N. (1981). Transposable elements in prokaryotes. Annu Rev Genet 15, 341-404.

Larkin, M. J., DeMot, R., Kulakov, L. A. \& Nagy, I. (1998). Applied aspects of Rhodococcus genetics. Antonie Leeuwenhoek 74, 133-153.

Lessard, P. A., O’Brien, X. M., Ahlgren, N. A., Ribich, S. A. \& Sinskey, A. J. (1999). Characterization of IS1676 from Rhodococcus erythropolis SQ1. Appl Microbiol Biotechnol 52, 811-819.

Mosser, D. M. \& Hondalus, M. K. (1996). Rhodococcus equi: an emerging opportunistic pathogen. Trends Microbiol 4, 29-33.

Nagy, I., Schoofs, G., Vanderleyden, J. \& DeMot, R. R. (1997). Transposition of the IS21-related element IS1415 in Rbodococcus erythropolis. J Bacteriol 179, 4635-4638.

Pelicic, V., Jackson, M., Reyrat, J. M., Jacobs, W. R., Gicquel, B. \& Guilhot, C. (1997). Efficient allelic exchange and transposon mutagenesis in Mycobacterium tuberculosis. Proc Natl Acad Sci US A 94, 10955-10960.

Pospiech, A. \& Neumann, B. (1995). A versatile quick-prep of genomic DNA from Gram-positive bacteria. Trends Genet 11, 217-218.

Powell, J. A. C. (1998). Genetic analysis in Rhodococcus sp. V49: the ohp gene cluster, pp. 264-289. PhD thesis, University of Cambridge.

Powell, J. A. C. \& Archer, J. A. C. (1998). Molecular characterisation of a Rhodococcus ohp operon. Antonie Leeuwenhoek 74, $175-188$.

Sekizaki, T., Tanoue, T., Osaki, M., Shimoji, Y., Tsubaki, S. \& Takai, S. (1998). Improved electroporation of Rhodococcus equi. J Vet Med Sci 60, 277-279.

Shao, Z. O. \& Behki, R. (1995). Cloning of genes for the degradation of the herbicides EPTC (S-ethyl dipropylthiocarbamate) and atrazine from Rhodococcus sp. strain TE1. Appl Environ Microbiol 61, 2061-2065.

Sonnhammer, E. L. L., Eddy, S. R., Birney, E., Bateman, A. \& Durbin, R. (1998). Pfam: multiple sequence alignments and HMM-profiles of protein domains. Nucleic Acids Res 26, 320-322.

Warhurst, A. M. \& Fewson, C. A. (1994). Biotransformations 
catalysed by the genus Rhodococcus. Crit Rev Biotechnol 14, 29-73.

Yao, W. S., Yang, Y. L. \& Chiao, J. S. (1994a). IS204 - an insertion sequence from Nocardia asteroides (mexicana) yp21. Plasmid 32, $262-269$
Yao, W., Yang, Y. \& Chiao, J. (1994b). Cloning vector system for Nocardia spp. Curr Microbiol 29, 223-227.

Received 1 May 2001; revised 23 May 2001; accepted 29 May 2001. 